\title{
Use of Integrated Thematic Teaching Materials Based on Problem Solving in Natural Science Learning in Elementary Schools
}

\author{
Harlinda Syofyan ${ }^{1}$, Zulela MS ${ }^{2}$, Mohamad Syarif Sumantri ${ }^{3}$ \\ \{soflynda@esaunggul.ac.id ${ }^{1}$, zulela@unj.ac.id ${ }^{2}$, mohamadsumantri@gmail.com ${ }^{3}$ \} \\ Universitas Negeri Jakarta, Indonesia ${ }^{123}$
}

\begin{abstract}
The purpose of this study is to determine the effectiveness of the use of integrated thematic teaching materials based on problem-solving skills developed in natural science learning in elementary schools. This research design applies two groups of respondents, namely the Experimental Class Group and the Control Class Group. This study refers to the concept of the pretest-posttest control group with the data analysis technique used is descriptive statistics and t-test. The results of this study indicate that the use of integrated thematic teaching materials developed in natural science learning is significant, thus it can be concluded that learning using thematic learning material is based on problem-solving skills in natural science learning can improve elementary school student learning achievement.
\end{abstract}

Keywords: Sciences, thematic, teaching materials

\section{Introduction}

Teaching materials are important in supporting the achievement of expected learning outcomes. Namely teaching materials that can hone students' cognitive, affective and psychomotor skills. Packaging good teaching materials by increasing student understanding in learning. Teaching materials with a scientific approach, besides that to the teaching materials should motivate students to not be lazy, do not get bored, and more eager to learn. So the development of scientific-based interactive teaching [1]. Balanced science teaching materials are teaching materials that have scientific literacy content. The content of scientific literacy includes science as a body of knowledge, science as a way of investigating, science as a way of thinking, and interaction between technological science and society [2]. Teachers should be creative in providing teaching materials that are able to stimulate students to think and solve problems. So that students will get used to cultivating their minds in solving problems both in learning and in solving problems in everyday life. In the classroom, it is necessary to use a learning model that can inspire students in processing ways and patterns of thinking. So that there is a need for serious planning for teachers and schools to achieve this situation, which ultimately moves students to be close to nature and the environment. teaching materials of natural science that can facilitate the students to be able to explore the object of science learning deeply and to improve their metacognitive ability [3].

In the study of Natural Science, knowledge gained through collecting data with experiments, observations, to produce an explanation of the problem being solved $t$ also with 
nature and its environment [4]. While the learning outcomes or achievement is the realization or division of potential skills or capacities that a person has. Mastery of learning outcomes by someone can be seen from their behavior, both behavior in the form of mastery of knowledge, thinking skills and motor skills [5]. The presentation of concepts in Natural Sciences teaching materials can begin with the phenomena that surround students and discuss them with various reviews and fields of study so that students sharpen their thinking in thinking and solving problems in their environment [6].

One method that can be applied to achieve the above goals is the learning method using problem-solving learning methods. Problem-solving method is a method used to provide learning stimuli to students to be able to make them think real and analyze, solve problems then draw conclusions from existing problems with steps or cycles 1) Identify problems, 2) Search for data for solve problems, 3) Establish strategies and hypotheses or temporary answers, 4) Test the truth of the hypothesis, 5) Make conclusions [7], dan that learning by solving problems would lead to better learning outcomes (effectiveness) and be more efficient for collaborative learners, whereas learning by studying worked examples would lead to better learning outcomes and be more efficient for individual learners [8]. This method can also make education at school more relevant to life, especially with the real world. Besides that, it is also able to sharpen students with creative and thorough thinking because in the learning process already involves a mental process in solving the problem at hand. So that familiarize students in their lives solving problems both in a family, society, and work later can be trained in this method. This is very suitable for integrative thematic learning.

Integrated thematic learning is a learning system that allows actively searching, exploring, and discovering holistic, meaningful, and authentic scientific concepts and principles that exist in the lesson, both students and individuals. This integrated thematic learning can provide direct experience to students in the learning process. This process is able to increase the ability of students to be stronger and understand the things they learn. And the achievement of integrated activities is effective teaching in terms of training/skills development specific to school age children [9]. Implementation of the integrative curriculum is expected to drive the implementation of the curriculum of characters that are beneficial to the students, such as understanding and mastery of teaching materials, the growth of the student's personal attitude toward wise on religious values and culture [10], [11].

In line with supporting the goals of national education through the formation of superior human resources, students must be directed to be able to build their own knowledge, independently and have skills that have the potential to actively participate in the country's development later. Based on the background above, this study aims to examine the effectiveness of integrated science-based teaching materials based on problem-solving in elementary schools.

\section{Method}

This research design applies two groups of respondents, namely the Experimental Class Group and the Control Class Group. This study refers to the concept of the pretest-posttest control group with the data analysis technique used is descriptive statistics and t-test. The subjects of this study are the students of grade 4 Elementary School State of Kelapa Dua West Jakarta, the sample population used was all IVA class students as many as 26 students than the Control Class and 26 students for the Class IVB Experiment Class. The experimental class 
group is given integrated mathematics teaching materials based on a problem -solving, while the Control Class Group is given teaching material that is followed by the school. The pretest was given before the use of teaching materials and the pretest was done after the use of teaching materials was given. Then compared the results of learning the pretest and posttest of each group (research data attached) [12].

The research treatment was given to the experimental group, namely the implementation of learning using integrated thematic science teaching materials based on problem-solving, while in the control group given the implementation of learning using teaching materials in the form of thematic books from schools.

Based on the variables studied, the statistical hypothesis was tested using an independent sample t-test to measure the difference between the experimental class and the control class by using SPSS version 25 for Windows software. The research data set can be accessed in osf.io Open Science Framework.

\section{Results and Discussion}

\subsection{Analysis of Pre-Test and Post-Test Results Data}

The results of the pre-test and post-test analysis can be seen in the following table.

Table 1. Analysis of Pre-Test and Post-Test Result

\begin{tabular}{lccccc}
\hline \multicolumn{1}{c}{ Class } & Test & N & Average & \% & Increase (\%) \\
\hline $\begin{array}{l}\text { Experimen } \\
\begin{array}{l}\text { Problem } \\
\text { Solving) }\end{array}\end{array}$ & Post-Test & 26 & 60.00 & 60 & 18 \\
Control & 26 & 77.85 & 78 & \\
(Convensional) & Pre-Test & 26 & 54.77 & 55 & 15 \\
\hline
\end{tabular}

Based on the table above, it can be stated that the results of the pre-test and post-test scores between the experimental class (problem-solving) and (conventional) controls have increased. The average pre-test results in the experimental class (problem-solving) is 60.00 with the number of students as many as 20 students, while in the post-test stage the average value is 77.85 . So that it can be concluded that there is an average value increase of $18 \%$. While in the control class (conventional) in the pre-test 54.77 and in the post-test was 70.15 . The control class uses school books with conventional methods, while the experimental class uses integrated thematic books with problem-solving methods.

\subsection{Normality and Homogeneity Test Results}

Data from the use of integrated thematic based problem-solving natural science teaching materials originated from a homogeneous population and had data that were normally distributed. This is indicated by the results of the pre-test analysis of teaching materials. This is supported by the number of students as many as 26 people. Based on the results of this prerequisite test, the next activity is to conduct a hypothesis test on teaching materials. 


\subsection{Hypothesis Test Results}

The hypothetical criteria from the t-test are:

- Ho: There is no significant increase in student learning outcomes by using the problem-solving method using conventional methods on integrated thematic learning in Natural Sciences at State of Elementary School of Kelapa Dua 06 Pagi.

- H1: There is a significant increase in student learning outcomes by using the problem-solving method using conventional methods on integrated thematic learning in Natural Sciences at State of Elementary School of Kelapa Dua 06 Pagi.

Based on the results of calculations using paired sample t-test with the help of SPSS 25 for windows to determine the difference between the experimental class and the control class on it is known that the value of Sig. (2-tailed) of $0,000<0,05$, because of the Sig. (2-tailed) of 0,000 smaller than 0.05 , it can be concluded that the use of problem-solving methods can improve student learning outcomes for Natural Sciences subjects.

Table 2. Test of Paired Sample

\begin{tabular}{|c|c|c|c|c|c|c|c|c|c|}
\hline & & Mean & $\begin{array}{c}\text { Std. } \\
\text { Deviation }\end{array}$ & $\begin{array}{c}\text { Std. } \\
\text { Error } \\
\text { Mean }\end{array}$ & Lower & Upper & $\mathbf{t}$ & df & $\begin{array}{c}\text { Sig. } \\
(2- \\
\text { tailed })\end{array}$ \\
\hline $\begin{array}{l}\text { Pair } 1 \\
\text { (Experiment) }\end{array}$ & $\begin{array}{l}\text { Pretest - } \\
\text { Posttest }\end{array}$ & -17.84615 & 3.33097 & 0.65326 & -19.19156 & -16.50074 & -27.319 & 25 & 0 \\
\hline $\begin{array}{l}\text { Pair } 1 \\
\text { (Control) }\end{array}$ & $\begin{array}{l}\text { Pretest - } \\
\text { Postest }\end{array}$ & -15.38462 & 3.20096 & 0.62776 & -16.67751 & -14.09172 & -24.507 & 25 & 0 \\
\hline
\end{tabular}

The results of this study indicate that integrated thematic teaching materials in problemsolving based Natural Sciences learning can improve student learning outcomes compared to student learning outcomes using conventional methods. Through problem-solving methods students are actively involved in learning. Students are given the freedom to explore lesson information based on solutions to problems that are sought by themselves. So that the subject matter has given is more understandable to students because they are actively involved and stimulate curiosity and interest in students will also be increased. This is supported by Suhendri's research about the problem-solving method improves mathematics learning outcomes compared to using conventional methods [13]. Because problem solving imposes a higher cognitive load for novices than does studying worked examples it was hypothesized that learning by solving problems would lead to better learning outcomes (effectiveness) and be more efficient for collaborative learners, whereas learning by studying worked examples would lead to better learning outcomes and be more efficient for individual learners and effective for guiding students' attention [8], [14] \& [15]. Then Ristiasari (2012) \& Syofyan (2016) in their research also stated that the method of problem-solving with mind mapping has shown positive results and improvements in critical thinking skills. Because problem-solving methods have provided opportunities for students to build their own knowledge, so that the knowledge gained becomes more meaningful [16], [17]. When the students solved the problems, they cooperated to create their problem-solving strategies. Thus it could be considered that the problem solving-mathematics classroom, which starting with open-ended 
problems and having sessions for students to solve the problems by themselves, encourages students to create their own problems and problem-solving strategy [16]. The teacher should not interfere with the students while they are trying to solve the problem, but students are encouraged to compare their methods with each other, discuss the problem, etc [18]. Other studies also state that problem-solving can increase a person's cognitive abilities to increase [20].

Then integrated thematic teaching materials are very helpful for student learning activities. Student activities problem-solving methods in science learning are included in the medium category. This can be seen from the posttest average value. This is probably because there are several indicators of problem solving activities that still need to be improved, for example in students 'ability to apply concepts and theories, ability to implement tools, develop instruments, students' skills in choosing data collection techniques, accuracy in collecting data, meticulous attitude students in checking the completeness of the data, attitude of confidence in presenting the results of the report.

In the relevant research that the results can help the schools determine how to best increase social studies instructional time, improve the quality of social studies education, and the positive effects of instilling civic competence among their students.[19], [20]. And then from the curriculum changes in the country of Uganda states that the appropriateness of the new curriculum initiatives to the structural realities of Ugandan classrooms, and calls for increased attention to the implementation process [21]. Thematic-Integrated e-portfolio media web blog based effectively improves the scientific literacy of students to reach the multidimensional level, in which students are able to take advantage of various concepts and demonstrate the ability to connect these concepts to daily life. Students understand how science, society, and technology are interrelated and influence each other. Students also demonstrate an understanding of the nature of science through his answer [22], In fact that the classroom atmosphere is comfortable and fun, students can learn to solve social problems and mutual respect, they get opportunities as possible to learn better, get the information quickly, apply materials directly in the context of daily life, and apply the principle of mastery learning.

\section{Conclusion}

The results of the study concluded that there were differences in learning outcomes in students using problem-based integrated thematic science-based teaching materials with science teaching materials using conventional methods. Learning outcomes of students using integrated thematic science-based materials based on problem-solving show increasing results. So it is advisable for Natural Sciences teachers to use integrated thematic based problemsolving teaching materials as teaching material.

\section{References}

[1] M. K. Abadi, H. Pujiastuti, and L. D. Assaat, "Development of Teaching Materials Based Interactive Scientific Approach towards the Concept of Social Arithmetic for Junior High School Student," J. Phys. Conf. Ser., vol. 812, no. 1, 2017.

[2] D. Lukito, A. Rusilowati, and S. Linuwih, "Pengembangan Bahan Ajar Ipa Terpadu Berbasis Literasi Sains Bertema Perpindahan Kalor Dalam Kehidupan,” Unnes Phys. Educ. J., 2015. 
[3] N. R. Dewi, S. Kannapiran, and S. W. A. Wibowo, "Development of digital storytelling-based science teaching materials to improve students' metacognitive ability," J. Pendidik. IPA Indones., vol. 7, no. 1, pp. 16-24, 2018.

[4] A. Widiyatmoko, "Pengembangan perangkat pembelajaran ipa terpadu berkarakter menggunakan pendekatan humanistik berbantu alat peraga murah,” J. Pendidik. IPA Indones., vol. 2, no. 1, pp. 76-82, 2013.

[5] H. Syofyan, "Motivasi," Pengaruh Gaya Belajar Dan Motiv. Berprestasi Terhadap Has. Belajar Ipa Mhs. Pgsd Univ. Esa Unggul, vol. 3, no. Sendi_U 3, p. 10, 2017.

[6] L. Yuliati, "Efektivitas Bahan Ajar Ipa Terpadu Terhadap Kemampuan Berpikir Tingkat Tinggi Siswa Smp,” J. Pendidik. Fis. Indones., vol. 9, no. 1, pp. 53-57, 2013.

[7] Syofyan Harlinda, "Penerapan Metode Problem Solfing Pada Pembelajaran IPA Untuk Peningkatan Kemampuan Berpikir Siswa," Penerapan Metod. Probl. Solfing Pada Pembelajaran IPA Untuk Peningkatan Kemamp. Berpikir Siswa, 2016.

[8] F. Kirschner, F. Paas, P. A. Kirschner, and J. Janssen, "Differential effects of problem-solving demands on individual and collaborative learning outcomes," Learn. Instr., vol. 21, no. 4, pp. 587-599, 2011.

[9] L. S. Tudor, "Primary School Skills Development through Integrated Activities," Procedia Soc. Behav. Sci., vol. 127, pp. 722-727, 2014.

[10] C. M. Ibrahim Zubainur, "Integrative Curriculum in Teaching Science in the Elementary School," J. Arts, Sci. Commer., vol. VI, no. 4, pp. 48-55, 2015.

[11] M. C. Liu and J. Y. Wang, "Investigating Knowledge Integration in Web-based Thematic Learning Using Concept Mapping Assessment," Educ. Technol. Soc., vol. 13, no. 2, pp. 25-39, 2010.

[12] H. Syofyan, "Data Pretest Postest." OSF, 2018.

[13] H. Suhendri, "Jurnal Formatif 3(2): 105-114 Suhendri \& Mardalena - Pengaruh Metode Pembelajaran Problem ... PENGARUH METODE PEMBELAJARAN PROBLEM SOLVING TERHADAP HASIL BELAJAR MATEMATIKA DITINJAU DARI KEMANDIRIAN BELAJAR," vol. 3, no. 2, pp. 105-114.

[14] T. van Marlen, M. van Wermeskerken, H. Jarodzka, and T. van Gog, "Effectiveness of eye movement modeling examples in problem solving: The role of verbal ambiguity and prior knowledge," Learn. Instr., vol. 58, pp. 274-283, 2018.

[15] M. Wang, P. A. Kirschner, J. M. Spector, and X. Ge, "Computer-Based Learning Environments for Deeper Learning in Problem-Solving Contexts," Comput. Human Behav., vol. 87, pp. 403-405, 2018.

[16] P. Intaros, M. Inprasitha, and N. Srisawadi, "Students' Problem Solving Strategies in Problem Solving-mathematics Classroom," Procedia - Soc. Behav. Sci., 2014.

[17] S. dan Halim, "Penerapan Metode Problem Solving Pada Pembelajaran IPA Untuk Peningkatan Kemampuan Berpikir Kritis Siswa (Penelitian Tindakan Kelas Siswa Kelas V di SDN 3 Kreo Tangerang). ISBN: 978-979-3649-96-2,” Pros. Semin. Nas. Multi Disiplin Ilmu Call Pap. Ke-2 Tahun 2016., pp. 966-876, 2016.

[18] C. E. Hmelo-Silver, M. Kapur, and M. Hamstra, "Learning through problem solving," in International Handbook of the Learning Sciences, 2018.

[19] J. Ollila and M. Macy, "Social studies curriculum integration in elementary classrooms: A case study on a Pennsylvania Rural School," J. Soc. Stud. Res., 2018.

[20] S.-C. (Angel) Wu and Y.-L. (Aldy) Chang, "Advancing Kindergarten Teachers' Knowledge and Capabilities of Differentiated Instruction Associated with Implementation of Thematic Integrated Curriculum," Procedia - Soc. Behav. Sci., vol. 177, pp. 246-250, 2015.

[21] H. K. Altinyelken, "Curriculum change in Uganda: Teacher perspectives on the new thematic curriculum," Int. J. Educ. Dev., vol. 30, no. 2, pp. 151-161, 2010.

[22] A. Wijayanti and M. A. K. Basyar, "The development of thematic-integrated E-portfolio me-dia web blog based to increase the scientific literacy of elementary teacher education program's student," J. Pendidik. IPA Indonesia., vol. 5, no. 2, pp. 284-290, 2016. 